\title{
Development of Primary Axosomatic Endings in the Anteroventral Cochlear $\mathrm{N}$ ucleus of Mice
}

\author{
Charles J. Limb and David K. Ryugo \\ Center for H earing Sciences, Johns H opkins University School of M edicine, Baltimore, M D 21205 USA
}

Received: 19 April 2000; Accepted: 3 May 2000; Online publication: 10 August 2000

\section{ABSTRACT}

The endbulb of $\mathrm{H}$ eld is a large synaptic ending that arises from the myelinated auditory nerve fibers. Endbulbs exhibit an elaborate pattern of terminal branching and produce extensive contact with the postsynaptic cell body. These structural features appear to underlie the tight coupling between presynaptic activity and postsynaptic spike discharges. As a first step toward understanding the relationship between environmental sounds and the development of these neural elements, we examined the age-related changes in the morphology of endbulbs of $\mathrm{Held}$ in $\mathrm{CBA} / \mathrm{J}$ mice, a strain known to retain good hearing throughout life. Neurobiotin was injected into the modiolus of the cochlea in CBA/ J mice ranging in age from postnatal day 1 to 7 months. Light microscopic analyses suggest that endbulbs of the $\mathrm{CBA} / \mathrm{J}$ mice develop from small bouton endings at birth into large, highly branched structures in adults. This increase in structural complexity occurs mostly during the second through eighth postnatal weeks, and general stages of development can be defined. In addition, we compared endbulb structure between adult CBA/ J mice and adult shaker-2 mice ( $\mathrm{M}$ yol $5^{\mathrm{sh} 2 / \mathrm{sh}^{2}}$ ) and heterozygous littermates ( $\mathrm{M}$ yo15 $5^{+/ \mathrm{sh} 2}$ ). The shaker-2 mouse carries a mutated myosin 15 gene that results in congenital deafness, presumably due to abnormally short stereocilia in hair cell receptors. Neurobiotin was injected into the modiolus of adult $\mathrm{CBA} / \mathrm{J}, \mathrm{M}$ yol $15^{\text {sh } 2 / \mathrm{sh} 2}$, and $M$ yo15 $5^{+/ s h 2}$ mice. Endbulbs of deaf adult $M$ yol $5^{\text {sh2/sh2 }}$ mice exhibited a striking reduction in terminal

Correspondence to: David K. Ryugo - Center For Hearing Sciences • Johns H opkins U niversity School of Medicine $\cdot 720$ Rutland Avenue - Baltimore, MD 21205. Telephone: (410) 955-4543; fax: (410) 6144748; email: dryugo@bme.jhu.edu branching compared with those of $\mathrm{CBA} / \mathrm{J}$ and $M$ yo15 $5^{+/ \text {sh } 2}$ mice. Notably, the abnormal endbulbs of $M$ yo15 $5^{\text {sh2/ sh2 }}$ mice do not resemble immature endbulbs of normal-hearing mice, suggesting that deafness does not simply arrest development.

Keywords: deafness, endbulbs of $\mathrm{H}$ eld, hearing, neurobiotin, shaker-2

\section{INTRO DUCTIO N}

The cochlear nucleus of the brain stem is the first synaptic station of the central auditory system receiving acoustic information from the peripheral end organ. Since neurons of the cochlear nucleus give rise to all ascending pathways, their organization plays a key role in the central processing of sound. Thus, it is important to know the normal synaptic relation ships of primary afferents with second-order neurons because any abnormalities in the cochlear nucleus are likely to have widespread consequences.

With in the anteroventral cochlear nucleus (AVCN), myelinated auditory ner ve fibers produce one or several large axosomatic endings known as endbulbs of Held ( $H$ eld 1893; Ramon y Cajal 1909). The endbulb is one of the largest synaptic endings in the brain (Lenn and Reese 1966), exhibits an elaborately branched appearance in adult animals (Ryugo and Fekete 1982), expresses an estimated 500-2000 synaptic active zones (Ryugo et al. 1996), and contacts a population of second-order neurons called spherical bushy cells ( Brawer and Morest 1975; Cant and Morest 1979; Ryugo and Fekete 1982). These features are presumed to reflect a highly secure synaptic interface, consistent with the suggestion that every presynaptic discharge produces a postsynaptic spike (Pfeiffer 1966). The postsynaptic spherical bushy cell exhibits 
rapid depolarizations and repolarizations, thereby maintaining the temporal fidelity of incoming signals (Romand 1978; O ertel 1983; M anisand M arx 1991). In addition, spherical bushy cells project to the superior olivary complex (Cant and Casseday 1986) where they form a circuit implicated in the processing of interaural timing differences (Yin and Chan 1990; Fitzpatrick et al. 1997). Thus, this component of the auditory path way faithfully preser ves the temporal changes and transients of acoustic streams necessary for the localization of sound sourcesin space and for the comprehension of speech (M oiseff and Konishi 1981; Takahashi et al. 1984; Blackburn and Sachs 1990).

Endbulb synapses exhibit several activity-related features. The morphologic complexity of endbulbs and their synaptic ultrastructure in cats with normal hearing have been shown to vary systematically with respect to levels of spike discharges (Ryugo et al. 1996). That is, end bulbs of relatively inactive auditory nerve fibers exhibit more but smaller terminal swellings and are associated with larger postsynaptic densities compared with endbulbs of relatively active fibers. This activityrelated feature of synaptic structure has been further explored by using deafness as an extreme form of activity reduction (Ryugo et al. 1997, 1998). The endbulbs of adult congenitally deaf white cats, where auditory nerve activity is greatly reduced, exhibit reduced branching and hypertrophied synaptic structures when compared with hearing littermates. However, a major concern regarding these observations was that the abnormalities in endbulb structure for congenitally deaf white cats might be the result of the genetic syndrome rather than a result of deafnessitself. Consequently, we sought a different animal model in order to test hypotheses developed from the cat data.

The mouse provides a useful model with which to address this issue because of its relatively uniform genetic background and the presence of many strains of mutants, some with point mutations causing deafness. The shaker-2 mouse has a mutation on the MYO 15 gene that causes an amino acid substitution from cysteine to tyrosine within the motor domain of the unconventional myosin 15 protein (Probst et al. 1998). Myosin 15 appears involved in the maintenance of the actin organization in the hair cells of the organ of Corti and vestibular epithelia. As a result of this substitution, stereocilia of homozygous mutants appear short and stubby, and the mice display phenotypic deafness and circling behavior (Deol 1954; Probst et al. 1998). There are early pathologic alterations in the organ of Corti, but cell loss in the spiral ganglion is undetectable until after 100 days postnatal (Deol 1954). The shaker-2 mouse mutation is homologous with human DFNB3, the gene associated with an autosomal recessive mutation that produces a nonsyndromic form of deafness
(Wakabayashi et al., 1998; Wang et al. 1998). Consequently, the shaker-2 mouse emerges as a model for understanding human deafness and for studying the effects of a natural form of deafness on brain development.

\section{MATERIALS AND METHODS}

\section{Subjects}

CBA/ J mice ( $n=27$ and of either sex) weighing between 1 and $35 \mathrm{~g}$ were studied at the following postnatal ages: 1 day $(n=4), 5-7$ days $(n=3), 12-14$ days $(n=3)$, 4 weeks $(n=5), 8-10$ weeks $(n=5)$, and 6-7 months $(n=7)$. The CBA/J mouse strain was selected because it retains good hearing across most of its life span (e.g., Henry 1983) and provides normal baseline data with which to make comparisons. Adult homozygous shaker-2 mice ( $M$ yol $5^{\text {sh2/ sh2 }, ~} n=4$ ) and heterozygous littermates ( $M$ yol $5^{+/ s h 2}, n=2$ ), between 8 and 11 weeks old, were also studied. Mice were obtained from a licensed vendor (Jackson Laboratories, Bar Harbor, ME) , and all subjects in this study appeared healthy, with normal respiratory activity, normal tympanic membranes, and no evidence of external or middle ear infection. All animal procedures were performed in accordance with the guidelines established by the NIH and with the approval of the Animal Care and $U$ se Committee of the Johns H opkins U niversity School of Medicine.

\section{Auditory brain stem responses (ABRs)}

The day of birth was counted as postnatal day 1 and each successive day was numbered consecutively. All mice older than 2 weeks were tested for behavioral responses to free-field auditor ystimuli ( loud handclap from behind). $\mathrm{CBA} / \mathrm{J}$ and $\mathrm{M}$ yo15 $5^{+/ \mathrm{sh} 2}$ mice exhibited a normal startle response, but the shaker-2 mice were unresponsive. Because we performed repeated $A B R$ tests on all animals up to the time of sacrifice, we did not surgically open the ear canals to collect data. Instead, we waited until the external ear canal was patent to the eardrum (21-24 days postnatal). For all mice 4 weeks of age and older, ABRs were recorded in response to clicks as a function of intensity. Mice were anesthetized using intraperitoneal injections of $3.5 \%$ chloral hydrate $(0.008 \mathrm{~mL} / \mathrm{kg})$ and xylazine hydrochloride $(0.006 \mathrm{mg} / \mathrm{kg})$. ABRs were recorded with a vertex electrode and an electrode inserted behind the pinna ipsilateral to the stimulated ear. Click levels were determined in $\mathrm{dB}$ peak equivalent SPL ( $d B$ peSPL) referenced to $1 \mathrm{kHz}$ by recording levels just inside the tip of a hollow ear bar using a calibrated microphone (Burkard 1984). The ear bar, coupled 
to an electrostatic speaker (Sokolich 1977), was then placed into the external ear canal. Clicks $(n=1000)$ of $100-\mu \mathrm{s}$ duration and alternating polarity were presented monaurally in 5-dB increments, starting at 0 $\mathrm{dB}$ and progressing to $95 \mathrm{~dB}$ peSPL. At each intensity level, $A B R s$ were recorded for 15 ms and then averaged (Tucker Davis Technologies, Gainesville, FL). Threshold was determined by examining the first two consecutive waveforms occurring within $8 \mathrm{~ms}$ of stimulus presentation that had peak-to-trough amplitudes greater than or equal to $0.5 \mu \mathrm{V}$ and an average rise time greater than or equal to $1.5 \mu \mathrm{V} / \mathrm{ms}$ for positive waveforms or less than or equal to $-1.5 \mu \mu \mathrm{V} / \mathrm{ms}$ for negative waveforms. After ABR testing, animals were allowed to recover for at least 24 hours prior to surgery.

\section{Adult animal injections}

Animals were anesthetized with an intraperitoneal injection of $3.5 \%$ chloral hydrate solution $(0.008 \mathrm{~mL} /$ $\mathrm{kg})$ and xylazine hydrochloride $(0.006 \mathrm{mg} / \mathrm{kg})$. When the mouse was areflexic to paw pinch, it was secured in a head holder with the right ear oriented downward. A left postauricular incision was made, and the soft tissue posterior to the external auditory canal was dissected free from the canal. An incision was made into the canal near the bulla, allowing visualization of the tympanic membrane. The tympanic membrane, malleus, and incus were removed, and the posterioinferior aspect of the bulla was chipped away using a finetipped rongeur and diamond bit drill with a 0.5-mmdiameter tip. The stapedial artery, which usually traverses the stapes footplate, was cauterized at its superior and inferior limits using a bipolar electric cautery. The stapes was removed from the oval window. A right angle hook was placed into either the round or oval window, and the lateral wall of the otic capsule was removed by gentle picking with the hook. The modiolus of the cochlea was located, and a hole was made into its core between the basal turn and apical halfturn using a size $0.01(100 \mu \mathrm{m})$ insect pin. A glass electrode with an inner diameter between 5 and 40 $\mu \mathrm{m}$ filled with a $5 \%$ neurobiotin solution in $0.1 \mathrm{M}$ potassium chloride was placed into the hole made by the insect pin. Neurobiotin was injected into the modiolus by passing $5 \mu \mathrm{A}$ of positive current ( $50 \%$ duty cycle) for 0.5-10 min through the micropipette. Following injection, the electrode was removed, incisions were closed, and the animal was allowed to recover for up to six hours.

\section{Neonatal injections}

For animals 5 days of age or younger, anesthesia was induced by hypothermia where pups were immersed in an ice-water bath after first being wrapped in a latex sleeve. Following cessation of movement and areflexia to paw pinch, the animalswere placed in a Petri dish on a bed of ice with the right ear down. A left postauricular incision was made, and soft tissue was aspirated away using the external auditory canal as a landmark. The middle ear ossicles were located and removed using a right angle hook. A small hole was then made through the oval window into the sensory neuroepithelium of the cochlea using a $100-\mu \mathrm{m}$ insect pin. With the use of a pipette, $0.3-0.5 \mu \mathrm{L}$ of $5 \%$ neurobiotin in $0.1 \mathrm{M}$ potassium chloride was injected into the oval window. The incision was then sutured closed and the mouse warmed for recovery.

\section{Tissue preparation}

After a recover y period of two to six hours, each mouse was administered a lethal dose of sodium pentobarbital. When the mouse was areflexic to a paw pinch, it was perfused through the heart with $5 \mathrm{~mL}$ of $0.1 \mathrm{M}$ cacodylate-buffered saline ( $\mathrm{pH}$ 7.3) containing $1 \%$ sodium nitrite, followed by $250 \mathrm{~mL}$ of $0.1 \mathrm{M}$ cacodylatebuffered fixative ( $\mathrm{pH} 7.2$ ) containing $2 \%$ glutaraldehyde and $2 \%$ paraformaldehyde. Immediately thereafter, the skin, cranium, and cerebellum were removed, a 30-g needle was placed through the right side of the brain stem parallel to the midline for orientation, and the animal's head was placed overnight at $4^{\circ} \mathrm{C}$ in the same fixative solution. The following morning, the brain was dissected from the skull. The cochlear nucleus was blocked with a razor blade, embedded in gelatin-albumin, and sectioned in the coronal plane on a Vibratome in alternate thickness of 75 and $50 \mu \mathrm{m}$.

All sections were collected in $0.1 \mathrm{M}$ cacodylate buffer ( $C B, p H ~ 7.3)$ and then incubated in a solution of $A B C$ Elite (Vector Laboratories, Burligame, $C A$ ) in $0.1 \mathrm{M} \mathrm{CB}$ overnight at $4^{\circ} \mathrm{C}$. The next morning, sections were rinsed several times in $0.1 \mathrm{M} \mathrm{CB}$, incubated in the dark for 60 minutes in a $0.05 \%$ solution of cacodylatebuffered 3,3'-diaminobenzidine (DAB, grade II, Sigma, St. Louis, MO) activated with $0.01 \%$ hydrogen peroxide, and rinsed several more times with $0.1 \mathrm{M}$ $\mathrm{CB}$. The $50-\mu \mathrm{m}$-thick sections were mounted on subbed slides, stained with cresyl violet, and coverslipped with Permount. The 75- $\mu \mathrm{m}$-thick sections were processed for electron microscopy and will not be discussed further in this report.

The cochlea contralateral to each injection was perfused through the round and oval windows using the above fixative and was postfixed overnight. Every cochlea was then placed in a solution of $0.1 \mathrm{M}$ EDTA containing $0.5 \%$ glutaraldehyde and $0.5 \%$ paraformaldehyde with daily changes for one week. X-ray analysis confirmed that all bone was decalcified, and then the cochleae were embedded in Araldite, sectioned at a thickness of $20 \mu \mathrm{m}$ on a rotary microtome using a 
carbide blade, collected in serial order, stained with $0.5 \%$ toluidine blue, and coverslipped with Permount.

\section{Data analysis: light microscopy}

The histological status of the cochleae was assessed using light microscopy. All sections were examined with respect to the appearance of hair cells, tectorial membrane, and ganglion cells. Observations were mapped onto half-turns of the cochlea.

Light microscopic analyses were concentrated in the five most anterior sections of the AVCN. This region was selected because in the adult mouse it is most heavily populated with endbulbs of $\mathrm{Held}$ and spherical bushy cells. All discrete, axosomatic endings were drawn in these sections in order to ensure a representative sampling for each age group. Photographs were collected using a light microscope and color CCD camera (3CCD H amamatsu). All endings were also drawn using a 100 $\times$ magnification oil immersion objective lens ( N.A. 1.25) and drawing tube (total magnification $\times 2500$ ). The cell perimeter was drawn if the nucleus and nucleolus were clearly defined. With younger animals ( $<2$ weeks of age), endbulb identification wasnot possible because endbulbs and spherical bushycellshad not yet developed their distinctive characteristics. Hence, in these young animals, we analyzed all labeled terminal swellings contacting cell bodies in the rostral AVCN.

Endbulbs from CBA/J mice (12 mice, 143 endbulbs), $M$ yol $15^{\text {sh2/ } / \text { sh2 }}$ deaf mice ( 3 mice, 26 endbulbs), and $\mathrm{M}$ yo $15^{+/ \text {sh } 2}$ hearing littermates ( 2 mice, 15 endbulbs) were collected and analyzed for this study. Endbulb drawings were digitized using a flatbed scanner (Agfa Fotolook) for purposes of fractal analysis. Fractal geometry has provided a quantitative descriptor of the complexity of natural structures (Mandelbrot 1982), and has been used to assess endbulb complexity (Ryugo et al. 1997). We applied the box-counting technique (Fractal Dimension Calculator v1.5), where a grid of squares having 11 different sizes is placed over the outline of the endbulb and, for each size $(s)$, the number of squares $N(s)$ that contain any portion of the endbulb is counted. The fractal dimension $D$ is given by the slope of the linear portion of the line when $\log [N(s)]$ is plotted vs. log $(1 / \mathrm{s})$, derived from the relationship $\log [N(\mathrm{~s})]=D$ $\log (1 / \mathrm{s})$. Because there is no preferred origin for the boxes with respect to the pixels in the image, multiple measures $\mathrm{N}(\mathrm{s})$ are computed from nine different box origins, and the graphed value of $\mathrm{N}(\mathrm{s})$ is the average from the different origins. Fractal values range between 1 and 2, and, because the fractal index is represented on a logarithmic scale, each increase of 0.1 in the fractal dimension represents a doubling of structural complexity (Porter et al. 1991).
Cross-sectional silhouette area wasused to represent the size of spherical bushy cells at each age. Thirty cells from each animal at each age group were traced with a drawing tube in order to determine the relationship between age and cell body size. A cell was chosen if it was located in the anterior portion of the AVCN, displayed a well-defined nucleus, and the nucleolus was clearly visible. For animals younger than 2 weeks of age, 30 cellsthat met nucleolar criteria were selected from the rostral AVCN for analysis. All cell tracings and a scale bar were scanned into a computer and digitized as bitmap drawings (Adobe Photoshop v5.0). The digitized images were then measured by computer-aided morphometry (NIH Image v1.61). Nuclear-to-cytoplasmic ratio was calculated by dividing the area of the nucleus over the total area contained by the cell membrane. Means, standard deviations, and $\mathrm{p}$ values (ANOVA, Statview v5.0, SAS Institute Inc., Cary, NC) are provided when appropriate.

\section{RESU LTS}

\section{Normal mouse observations}

ABR data. ABRs were obtained for all CBA/J mice 4 weeks of age or older. We did not test younger animals because the external ear canal was not guaranteed to be patent. Thresholds were determined for both ears. Representative ABR tracings from one 4-week-old animal and one 7-month-old animal are shown in Figure 1. The mean threshold for hearing in all CBA/ J mice used in this study was $41.7 \pm 7.1 \mathrm{~dB}$ peSPL, a value consistent with those previously reported (Wenngren and Anniko 1988; Mikaelian and Ruben 1965; Hunter and Willott 1987; Zheng et al. 1999). At 4 weeks of age $(n=8)$, the mean threshold for hearing was $45.4 \pm 9.0 \mathrm{~dB}$ peSPL. At 8-10 weeks of age $(n=6)$, the mean threshold was $40.2 \pm 5.8 \mathrm{~dB}$ peSPL. At 7 months of age $(n=9)$, the mean threshold was $39.3 \pm 5.0 \mathrm{~dB}$ peSPL. These differences were not statistically significant (ANOVA, $p>0.1$ ), indicating that $A B R$ thresholds are stable by 4 weeks of age.

Endbulb development. Postnatal days 1-7: The newborn mouse weighed $1.33 \pm 0.1 \mathrm{~g}$ and its cochlear nucleus was small ( $<0.8 \mathrm{~mm}$ in length). The internal structure of the ventral division was characterized by tightly packed cell bodies. Each cell body contained scant cytoplasm but housed a prominent nucleus. The ventral division was clearly separated from the dorsal division by a lamina of granule cells, and the dorsal division already exhibited its characteristic layering. Neurobiotin-labeled auditory nerve fibers entered from the ventrolateral aspect, traveled dorsally a short distance, and bifurcated into ascending and descending branches. Individual fibers were thin $(<0.5 \mu \mathrm{m}$ in 
CBA/J, 4-week Old

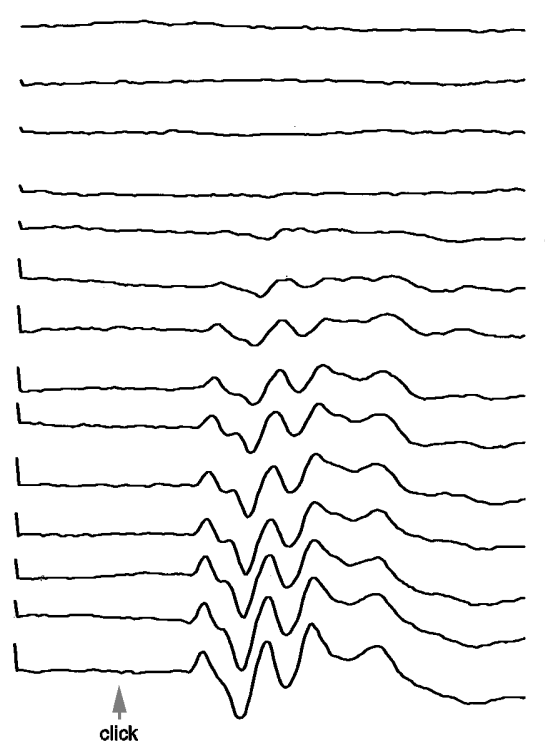

CBA/J, 7-month Old

$10 \mathrm{~dB}$ peSPL

$20 \mathrm{~dB}$ peSPL

$30 \mathrm{~dB}$ peSPL

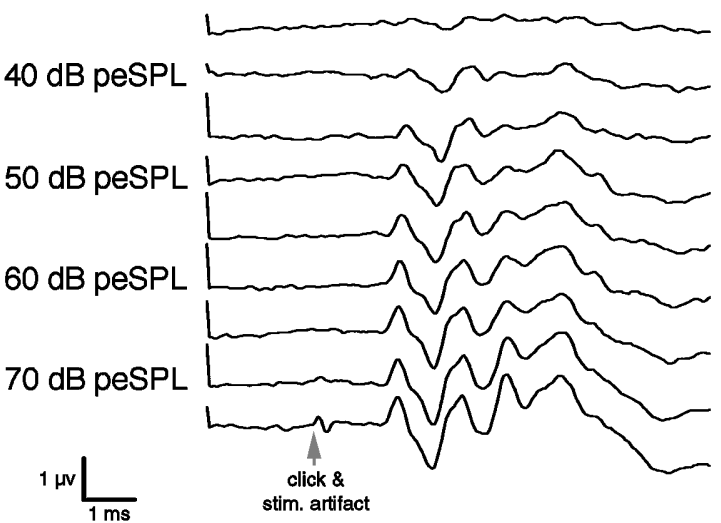

FIG. 1. Representative auditory brainstem response (ABR) recordings of normal CBA// mice, aged 4 weeks (left) and 7 months (right) in response to click stimuli. The gray arrows indicate the presentation of each click. The mean threshold of CBA/J mice $(n=23)$ was $41.7 \pm 7.1 \mathrm{~dB}$ peSPL. Thresholds do not show any significant change between 4 weeks and 7 months.
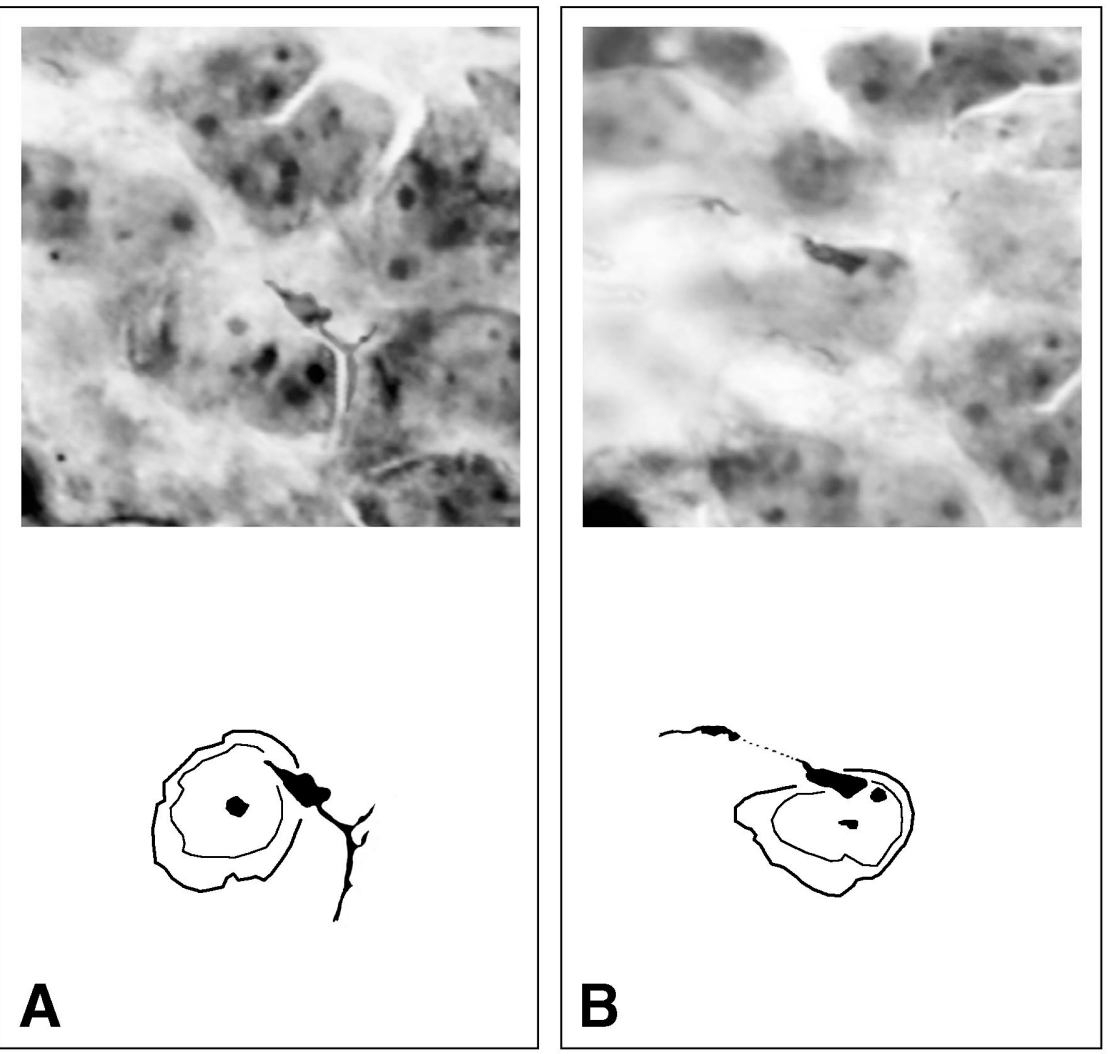

$10 \mu \mathrm{m}$

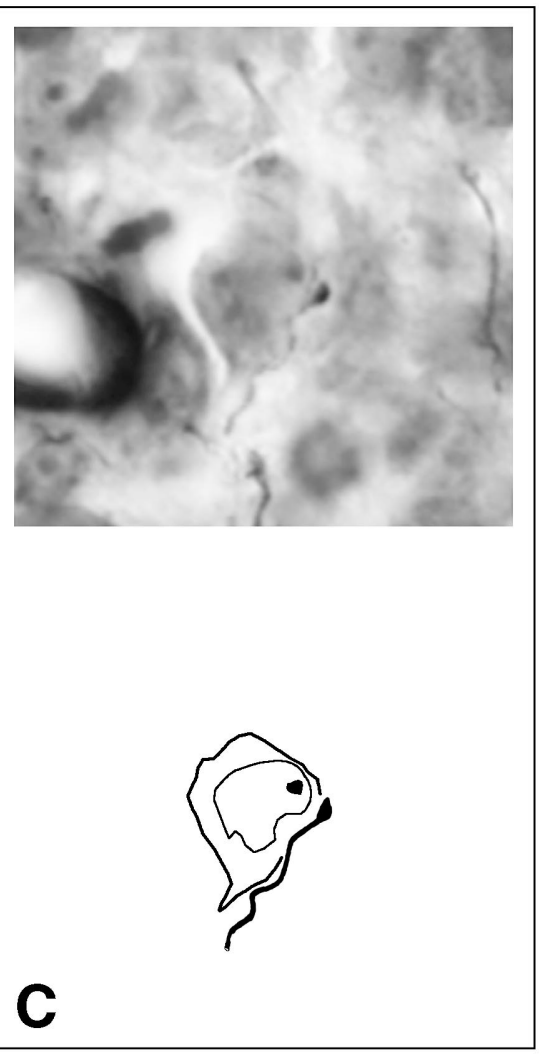

c

A/] mice. The endings are small, in some cases resembling boutons $(\mathbf{C})$ or in other cases appearing more elongated (B) or triangular (A). Cells in the rostral AVCN of the neonatal mouse are tightly packed, as seen in $\mathbf{A}$, with a great degree of variability in shape of both cell membrane and nuclear envelope. 

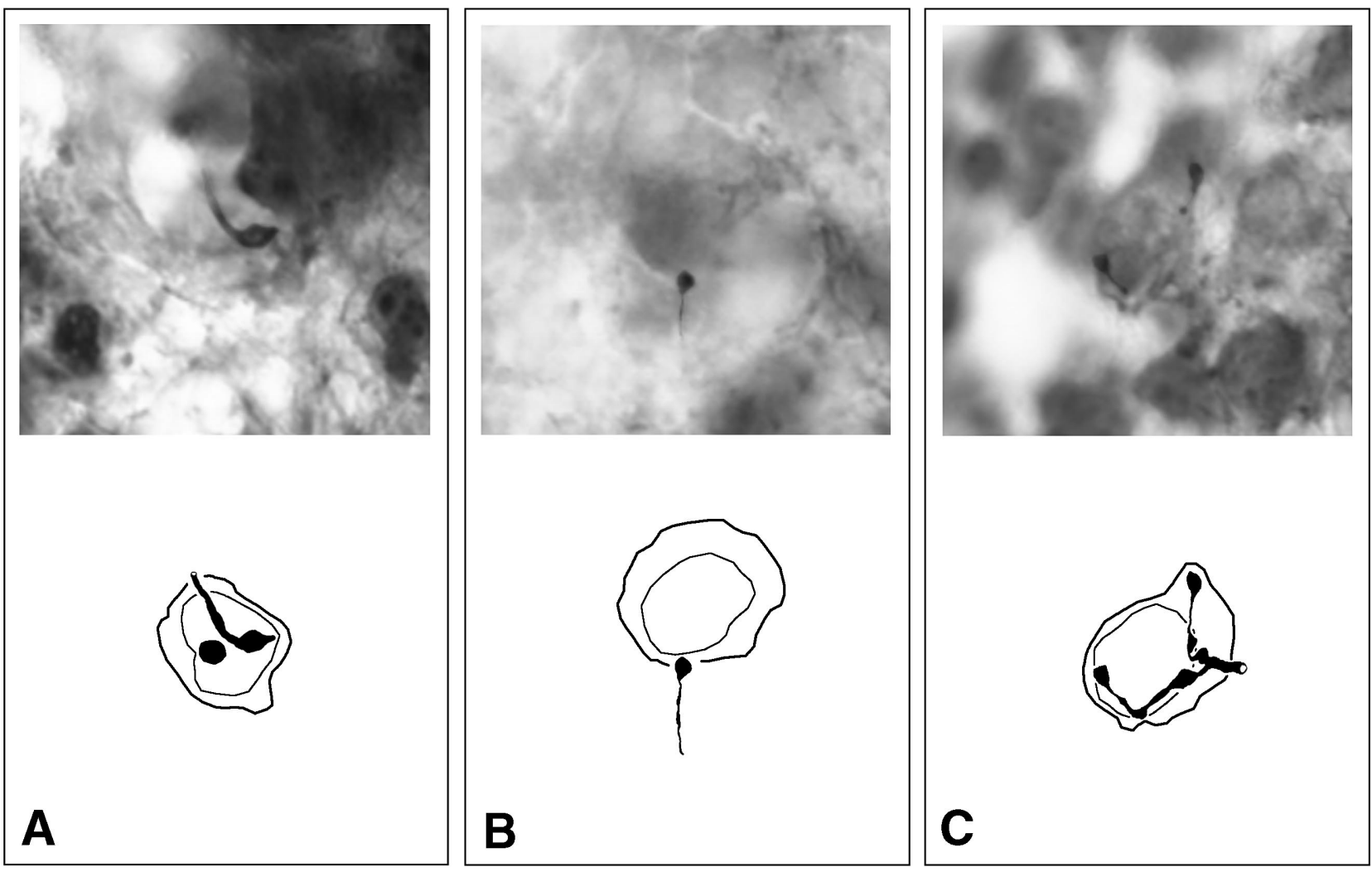

\section{$10 \mu \mathrm{m}$}

FIG. 3. Three neurobiotin-labeled endings from 1-week-old CBA/J mice. The endings are similar to those of 1-day-old mice, resembling small boutons that approach and impinge upon a cell body. In some cases, the endings appear as a bouton doublet (C) but do not give

diameter) and relatively unbranched. At the rostral end of each fiber, a small terminal swelling (1-3 $\mu \mathrm{m}$ in diameter) could be located (Fig. 2). U sually, the swellings appeared as rounded boutons (Fig. 2C), but the contour of the swelling could also be elongated or triangular (Fig. 2A,B). In a few instances, the axon terminal branched and formed a pair of terminal swellings, but en passant swellings were not apparent along the terminal branches. These terminal swellings do not resemble the mature endbulbs of $\mathrm{H}$ eld, but their axosomatic contact in the rostral AVCN is taken as evidence for their identity.

Between postnatal days 1 and 7, the mouse grew slowly and the light microscopic appearance of the swellings of auditory nerve fiber did not undergo much change. By postnatal day 7 , the mouse weighed $3.25 \pm 0.3 \mathrm{~g}$ but swellings still appeared as small buds (Fig. 3). Some of the endings were boutonlike in shape (Fig. 3A). Occasionally, two buds emanated from one fiber and formed a doublet onto the same cell body (Fig. 3C). The buds themselves did not give rise to branches.

Neurons in the rostral AVCN cannot be separated rise to branches at this age. The cell bodies, which are not easily seen in these photomicrographs, still have an irregular contour with frequent membrane invaginations and have almost doubled in size during the first week of life.

into morphological groups on the basis of Nissl patterns or somatic shapes at postnatal day 7. In adults, neurons in this location are called spherical bushy cells and are described as having a round cell body, a centrally placed round nucleus surrounded by a cytoplasmic "necklace" of Nissl bodies, and a perinuclear Nissl cap (O sen 1969; Cant and Morest 1979; Webster and Trune 1982). In the neonatal mouse, the cell bodies were angular in shape and their surface was invaginated, sometimes more than once, producing a jagged appearance. In addition, the nuclear envelope was irregular and a perinuclear Nissl cap was not observed. The mean somatic silhouette area at this age was $62.9 \pm 13.8 \mu \mathrm{m}^{2}$.

Although the nuclear and cytoplasmic characteristics of cells in the rostral AVCN did not change during the first week, cell body size doubled, exhibiting a mean silhouette area of $114.0 \pm 14.7 \mu \mathrm{m}^{2}$. The cell outline still had frequent invaginations, but the overall impression was that these invaginations were less pronounced and that cell shape was less angular. The nuclear envelope appeared irregular in contour, the chromatin was generally dispersed, and there was no 

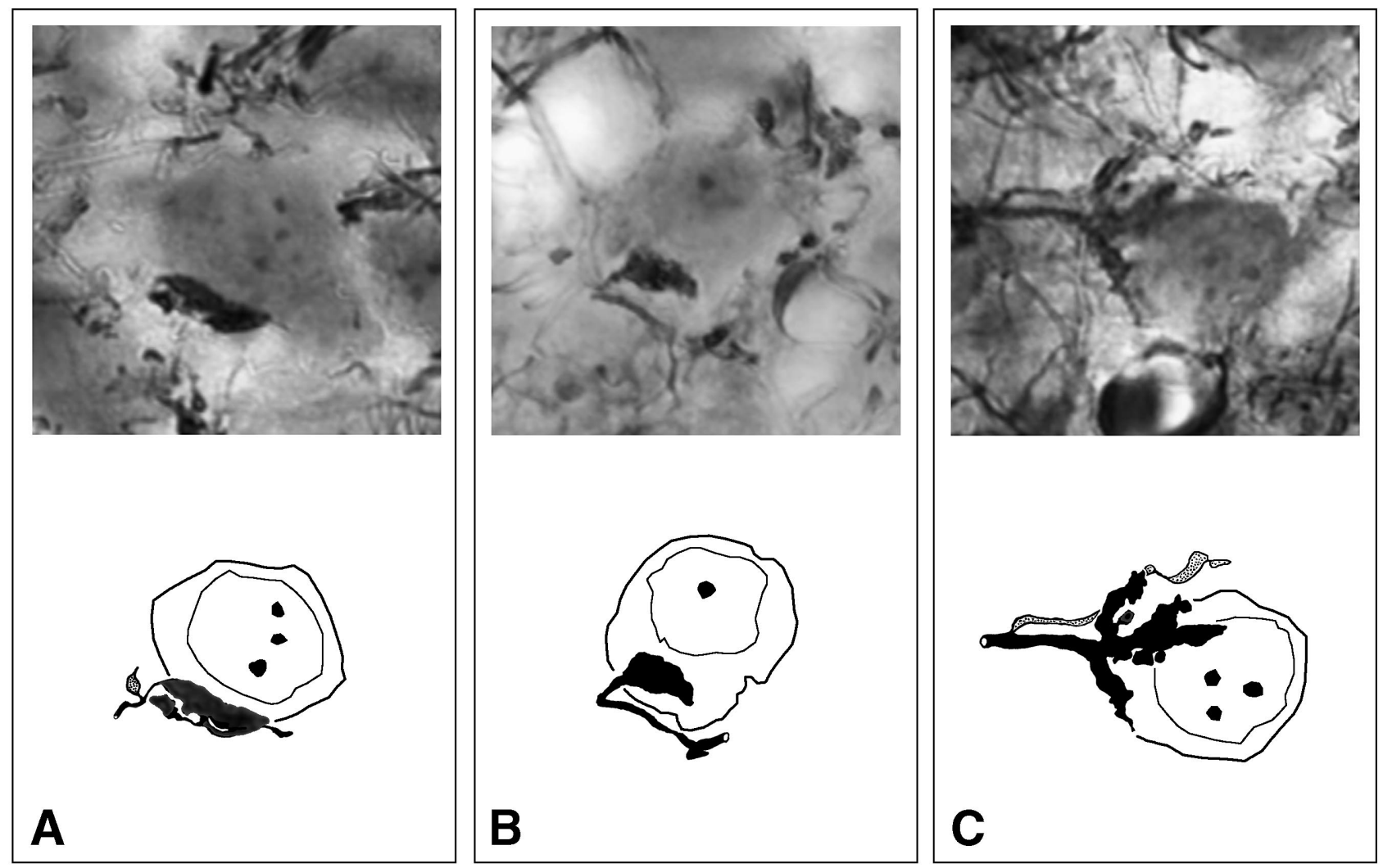

\section{$10 \mu \mathrm{m}$}

FIG. 4. Three neurobiotin-labeled endings from the AVCN of 2week-old CBA/J mice. The endings have undergone significant changes in morphology and can be identified as nascent endbulbs. Although they still appear relatively simple, there has been a 10- to 15 -fold increase in size during this second week. In a few cases (C), endings exhibited a coarse pattern of branches in which the parent axon gives rise to several smaller endings. The cells have also increased in size, displaying more regular contours and perinuclear $\mathrm{N}$ issl caps characteristic of spherical bushy cells (B and $\mathbf{C}$ ).

be seen in stained, light microscopic preparations, revealing the signature characteristic of spherical bushy cells. The contour of the cell was more regular than that at 1 week of age. The somatic invaginations were fewer and smaller and now appeared as slight indentations or concavities in the cell surface. The overall shape of the cells was oval to round. The nuclear envelope appeared more regular in contour as well, and clearly visible nucleoli emerged.

Postnatal week 4: CBA/J mice have reached roughly half their final body weight $(17.41 \pm 2.9 \mathrm{~g})$ and terminal swellings have been replaced by endings with definite branches (Fig. 5). These endings were clearly identifiable as nascent endbulbs, where a central trunk (2-4 $\mu \mathrm{m}$ in diameter) often gave rise to more branches with en passant swellings and irregular terminal swellings. The main branch could divide into two to three additional branches, each of which was nearly the same in caliber as the parent axon ( Fig. 5A,B). The branches were distinct from each other and did not extend far from the main trunk (Fig. $5 \mathrm{C}$ ).

By this age, the cell body of the spherical bushy cell reached its adult size. The mean cross-sectional area ette area of $163.9 \pm 18.5 \mu \mathrm{m}^{2}$. A perinuclear cap could 

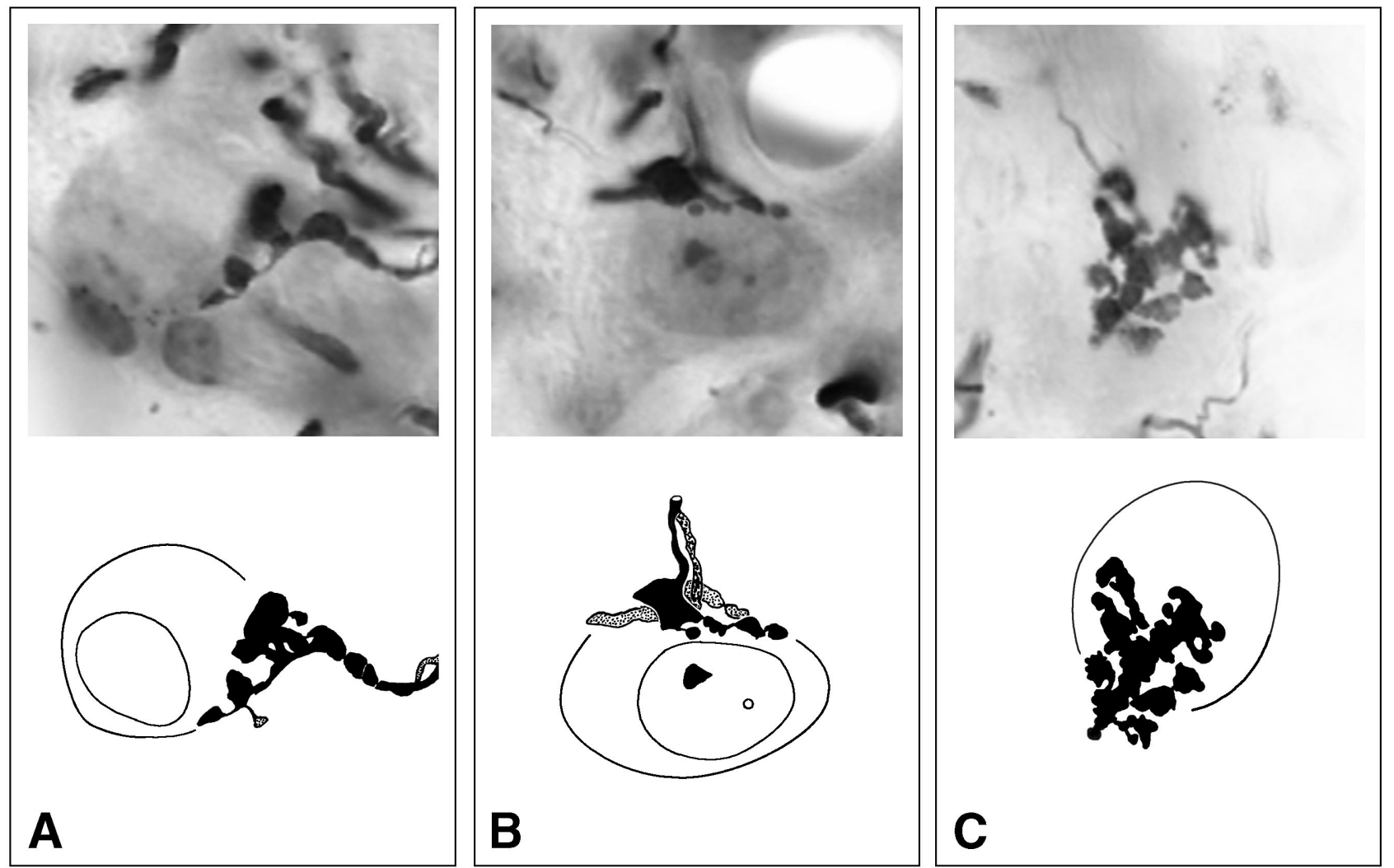

$10 \mu \mathrm{m}$

FIG. 5. Three neurobiotin-labeled endbulbs from 4-week-old CBA/ J mice. By this age endbulbs have a central trunk that usually gives rise to two or three definite branches, each of which has en passant swellings and boutonlike terminations. The branches do not extend very far from the main trunk. The spherical bushy cell has reached its adult size, and the cell surface has lost almost all irregularities or invaginations. The nuclear envelope is clearly visible, and a perinuclear $\mathrm{N}$ issl cap is generally noted as a faintly visible ring around one side of the nucleus (not clearly seen here in the focal planes shown).

rise to more branches with en passant swellings and irregular terminations, yielding an elaborate threedimensional arrangement that clasped the cell body. Spherical bushy cells exhibited a prominent perinuclear Nissl cap and had a mean cross-sectional area of $189.8 \pm 26.4 \mu \mathrm{m}^{2}$.

From 2 to 7 months of age, mice continued to gain weight ( $34.36 \pm 2.9 \mathrm{~g})$, but endbulb morphology did not change significantly (Fig. 7). The mature spherical bushy cell was characterized by a centrally located nucleus with a distinct perinuclear Nissl cap and a prominent nucleolus (e.g., Fig. 7B). The mean crosssectional area of spherical bushy cells in 7-month-old animals was $219.10 \pm 50.2 \mu \mathrm{m}^{2}$.

\section{Deaf mouse observations}

ABR data, shaker-2 mice. $M$ yol $15^{\text {sh } 2 / \text { sh } 2}$ mice, 8-11 weeks of age, exhibited constant circling behavior and were noticeably smaller ( $19.25 \pm 0.6 \mathrm{~g}$ ) than CBA/ J mice of comparable age. At 6 months, M yol $5^{\text {sh } 2 / \text { sh2 }}$ mice weigh $25.71 \pm 1.3 \mathrm{~g}$, approximately $75 \%$ of the weight of age-matched CBA/ J mice. They exhibited no evoked of the somatic surface. The branches themselves gave 

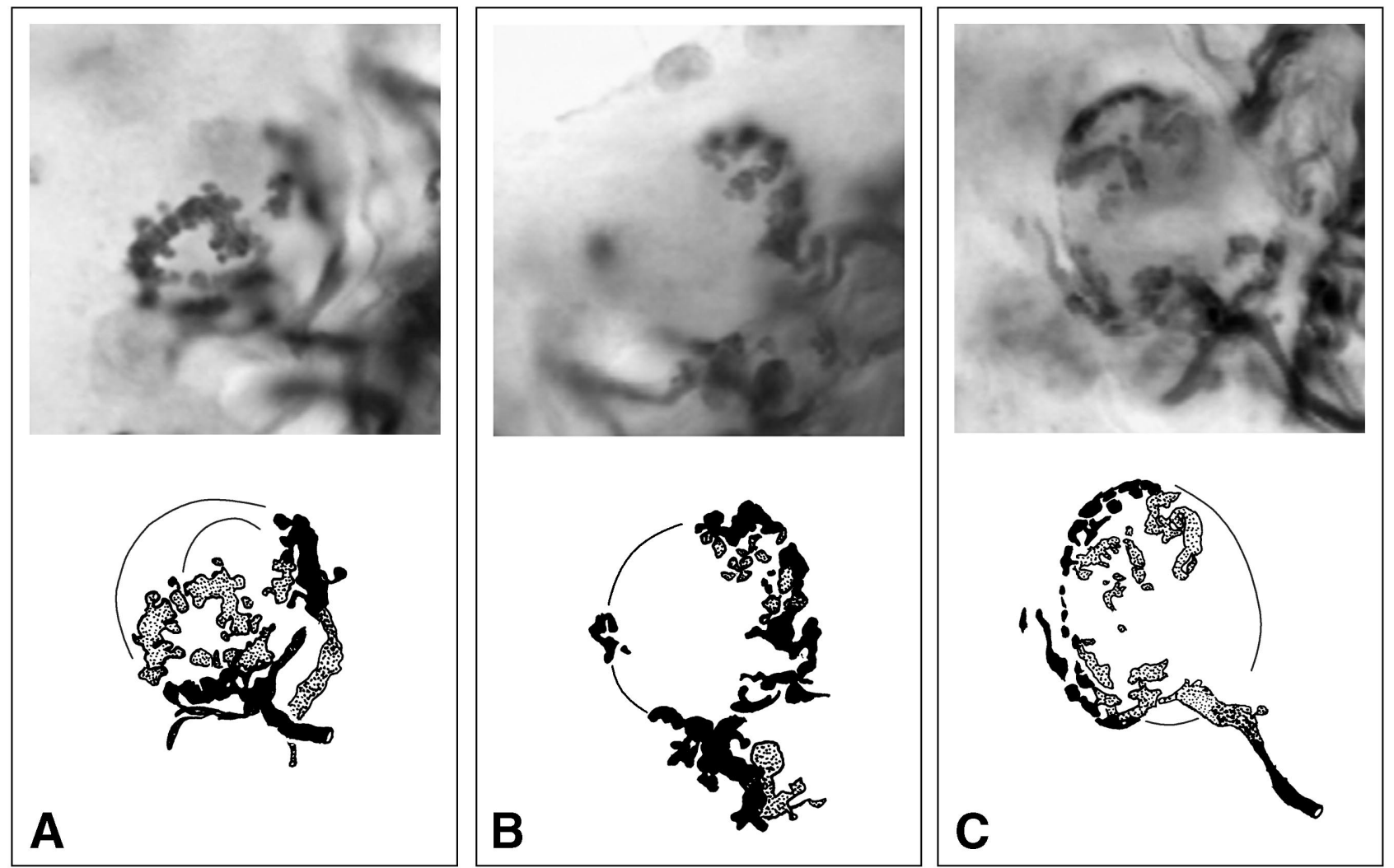

$10 \mu \mathrm{m}$

FIG. 6. Three neurobiotin-labeled endbulbs from 9-week-old CBA/ $J$ mice. At 9 weeks of age $C B A / J$ mice have reached adulthood. The terminal arborization is clearly definable as an endbulb. O ne can usually identify a central trunk that gives rise to branches that are longer and more varied in arrangement than at 4 weeks of age. The branches themselves give rise to other small branches with en passant swellings and complex terminations. The stippled regions indicate portions of the endbulb that are in a more superficial focal plane than the blackened regions. The spherical bushy cell has achieved its adult size and shape. potentials in response to clicks up to $95 \mathrm{~dB}$ peSPL (Fig. 8) . Although heterozygous $M$ yo15 $1 /$ sh2 littermates were also small ( $23.19 \pm 0.6 \mathrm{~g})$, they exhibited ABR thresholds to clicks ( $38.5 \pm 3.5 \mathrm{~dB}$ peSPL) that had similar values to what we recorded in CBA/J mice of the same age (Fig. 1).

Cochlear morphology. The histologic appearance of the cochleae of $\mathrm{CBA} / \mathrm{J}$ and $\mathrm{M}$ yo15 $5^{+/ \mathrm{sh} 2}$ mice was normal. In contrast, the cochleae of $M$ yol $5^{\text {sh2/ sh2 }}$ mice were distinctlyabnormal. A general histopathologic description for the cochleae of $\mathrm{M}$ yo1 $5^{\text {sh } 2 / \mathrm{sh} 2}$ mice was published previously (Deol 1954), and our data are generally consistent with this earlier report. Briefly, the tectorial membrane was conspicuously swollen in the apical turn of the cochlear duct and became thinner by the middle half turn and remained thin to the basal end. Throughout, however, the tectorial membrane failed to extend over the region of outer hair cells ( $\mathrm{OHCs}$ ). Inner hair cells were present in the apex although their absence became evident in the middle half turn and they were mostly gone in the base. OHCs were more affected. In the apex, OHCs of row 3 were often missing. Progressively more $\mathrm{OHCs}$ were absent throughout the rows in the middle half turn of the cochlear duct, and there were few if any OHCs in the base. The tunnel of Corti was consistently intact in the apex, but outer pillar cells were sometimes absent in the lower middle turn of the cochlear duct, and the tunnel was collapsed in the base. In one cochlea virtually all hair cells were present, and in another virtually all hair cells were absent. Irrespective of the appearance of the organ of Corti, spiral ganglion cells were present throughout Rosenthal's canal for all cochleae of $M$ yol $15^{\text {sh } 2 / s h 2}$ mice. There were a few empty spaces, 20-25 $\mu \mathrm{m}$ in diameter, scattered throughout Rosenthal'scanal, but mostly in the basal half turn; these spaces seemed to represent sites of ganglion cell loss.

Endbulb morphology. The diameters of labeled auditory nerve fibers from 2-month-old deaf ( $2.88 \pm 0.4$ $\mu \mathrm{m})$ and hearing $(2.9 \pm 0.4 \mu \mathrm{m})$ mice were comparable (ANOVA, $p>0.3$ ). The appearance of endbulbs from $M$ yol $5^{\text {sh2/ sh2 }}$ mice, however, was notably different from that of $\mathrm{M} \mathrm{yo15^{+/ } \text { sh2 }}$ littermates and normal-hearing CBA/ J mice of the same age. Adult hearing mice exhibit endbulbs with elaborate arborizations ( Figs. 6 , $7,9 \mathrm{~A}$ ). Most striking for the deaf $\mathrm{M}$ yol $5^{\mathrm{sh} 2 / \mathrm{sh} 2}$ mice was 

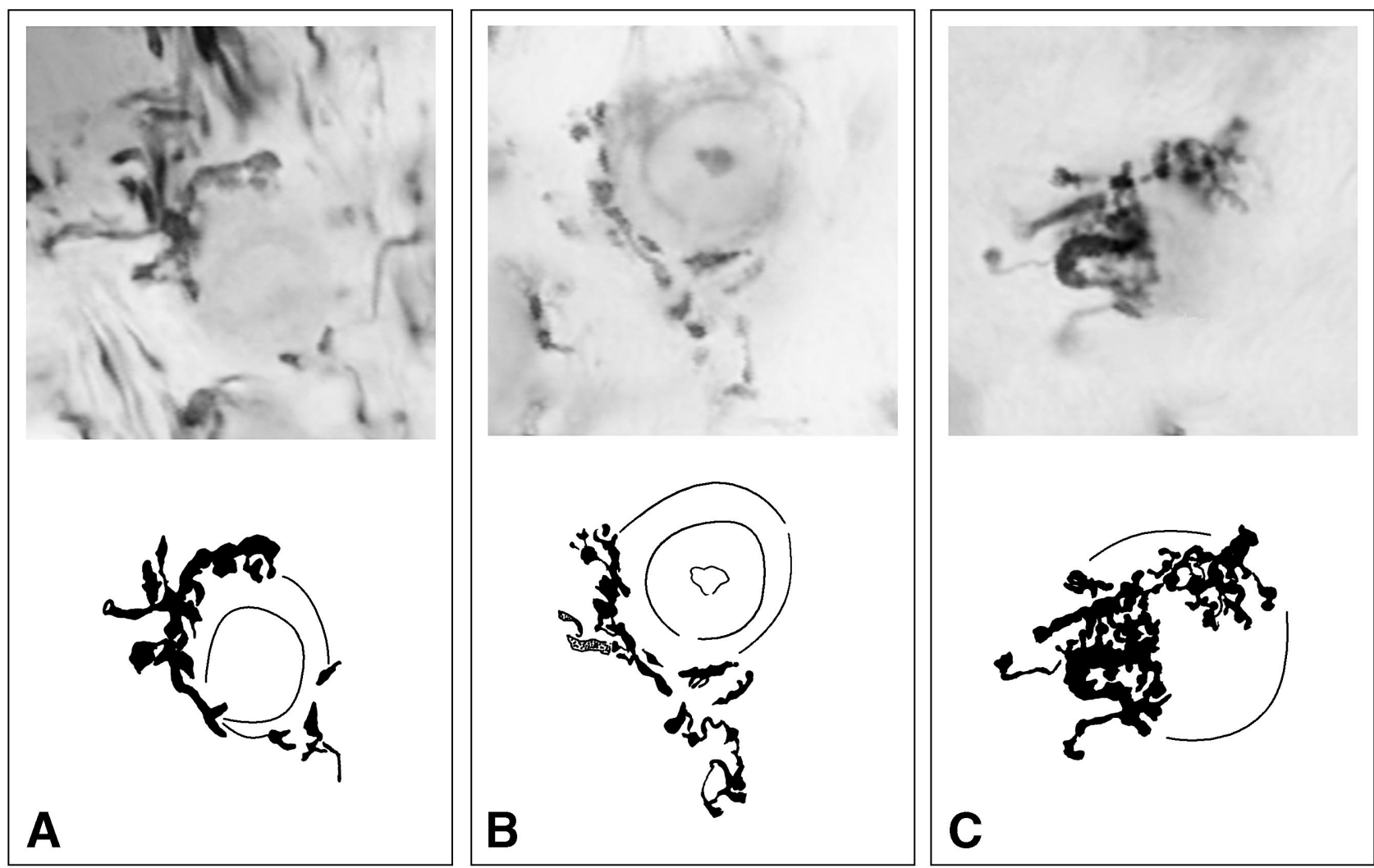

\section{$10 \mu \mathrm{m}$}

FIG. 7. Three neurobiotin-labeled endbulbs from 7-month-old CBA/ J mice. The complex pattern of branches seen in 9-week-old mice persists at least until 7 months of age. Endbulbs have a central trunk that gives rise to numerous branches and small filopodia, which in

Homozygous Mutants (Myo15 sh2/sh2) turn give rise to further branches and filopodia. The caliber of the branches appears slightly finer than at 9 weeks of age. The mature spherical bushy cell has a centrally located nucleus with a distinct perinuclear $\mathrm{N}$ issl cap and a prominent nucleolus (panel B).

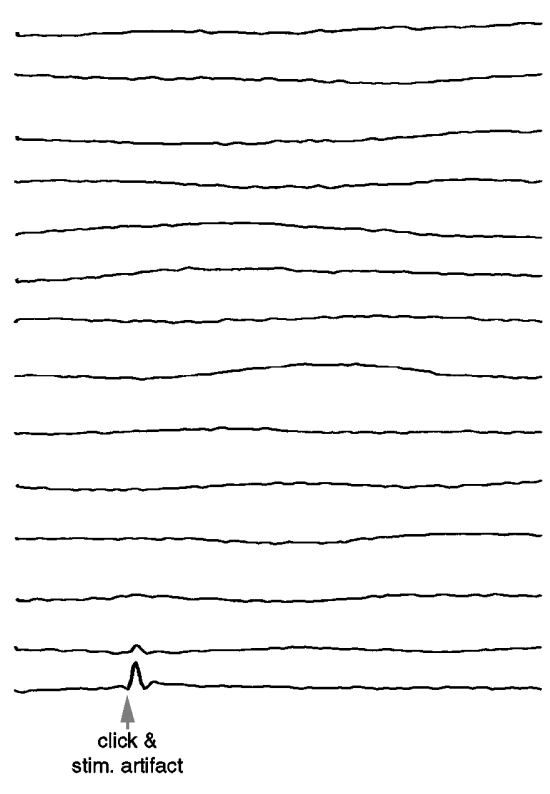

FIG. 8. Representative auditory brainstem response (ABR) recordings from deaf $M y 015^{\text {sh2/sh2 }}$ mice (left) and Myo15 $5^{+/ s h 2}$ littermates (right). No evoked responses were observed for $M$ yo15 $5^{\text {sh2/sh2 }}$ mice even after presentation of clicks up to $95 \mathrm{~dB}$ peSPL.

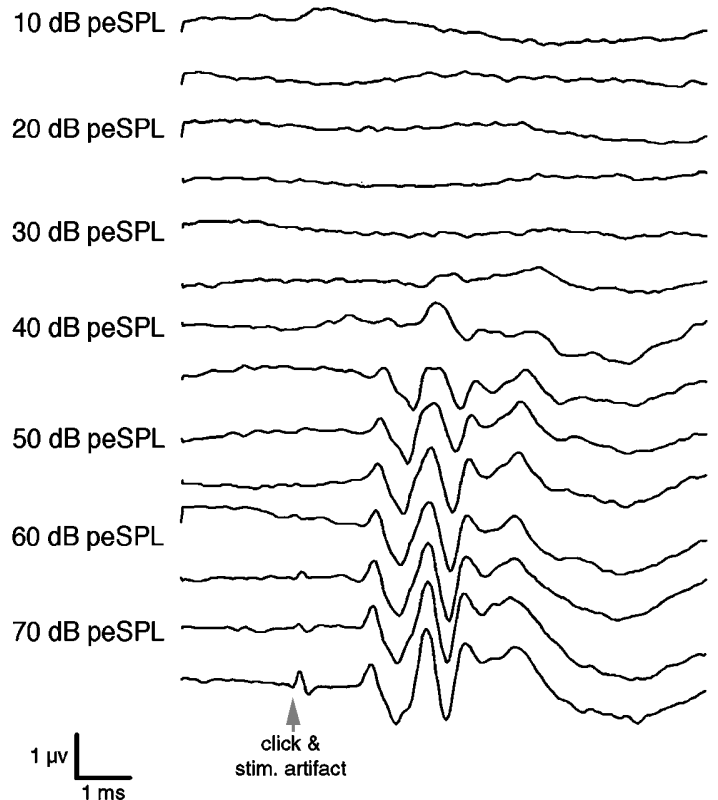

\section{Heterozygous Littermates $\left(M_{\left.y 015^{+/ s h 2}\right)}\right.$}

(Right), Myo15 $5^{+/ s h 2}$ littermates are shown to have normal hearing in response to click stimuli, with a mean threshold of $38.5 \pm 3.5 \mathrm{~dB}$ peSPL. The gray arrows indicate the presentation of the click stimulus. 


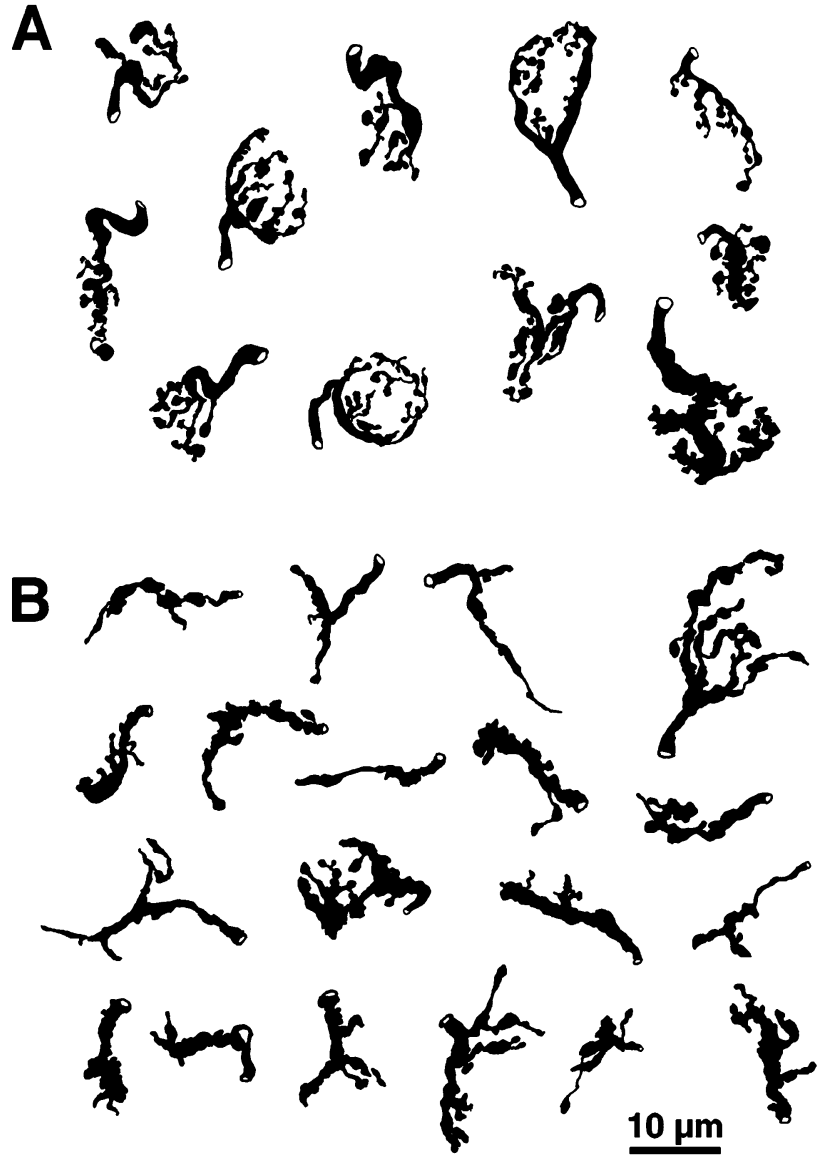

FIG. 9. Drawing tube reconstructions of neurobiotin-labeled endbulbs from adult $\mathrm{M}$ yo $15^{+/ \mathrm{sh} 2}$ mice. These endbulbs are representative of Myo15 $15^{+/ s h} 2$ mice and notably similar in appearance to those of normal-hearing CBA/J mice. B. Representative examples of drawing tube reconstructions of endbulbs taken from deaf adult M yo $15^{\text {sh2/sh2 }}$ mice. The endbulbs exhibit variable branching, ranging from relatively simple (upper left example) to quite extensive (upper right), but overall there is a decrease in structural complexity. Many of the endbulbs appear stunted in shape with few branches. The endbulbs of shaker-2 mice do not resemble those of normal mice at younger ages, suggesting that deafness does not simply arrest endbulb development.

a decrease in the complexity of endbulb branching (Fig. 9B). The main trunk was thick with irregular bumps but without interconnecting filaments or secondary and tertiary branching. Endbulbs from deaf mice could exhibit more extensive branching and present a near-normal appearance, but such occurrences were rare. Fractal analysis ( described later) confirmed the similarities in endbulb structure among the hearing mice and the clear differencesin endbulb structure when comparing hearing with deaf mice (Fig. 10, bottom panel).

Spherical bushy cell size. The somatic size of spherical bushy cells in CBA/ J mice was plotted with respect to age (Fig. 10, top panel). There was a rapid, statistically significant age-related increase in the average size of spherical bushy cells in the first month of life. Cell body size at birth was $62.9 \pm 13.8 \mu \mathrm{m}^{2}$, increased to $204 \pm 36.7 \mu \mathrm{m}^{2}$ at 4 weeks $(p<0.05)$, and remained constant out to 7 months $(p>0.45)$.

The body weight of $\mathrm{M}$ yol $15^{\text {sh } 2 / \text { sh } 2}$ and myo $15^{+/ \text {sh2 }}$ mice was consistently less than age-matched CBA/ J mice. Likewise, the size of their spherical bushy cells was smaller than that of adult CBA/J mice. Deaf $M$ yol $5^{\text {sh2/sh2 }}$ mice exhibited somatic silhouette areas of $147.68 \pm 26.9 \mu \mathrm{m}^{2}$, whereas hearing myo15 $5^{+/ \mathrm{sh} 2}$ littermates exhibited a mean of $150.59 \pm 32.8 \mu \mathrm{m}^{2}$. A comparison of cell body size among the three groups of mice demonstrated no difference between $M$ yol $5^{\text {sh } 21}$ sh2 and myo15 $1 /$ sh2 mice $(p>0.40)$ but a significant difference when each is compared with $C B A / J$ mice (ANOVA, $p<0.01$ ). These observations suggest that cell body size is related to strain differences rather than deafness.

Fractal analysis of endbulb complexity. We calculated the fractal index of CBA/ J endbulb silhouettes with respect to age in order to quantify developmental features (Fig. 10, bottom panel). The mean fractal index of endbulbs progressively increased with age, beginning at $1.02 \pm 0.02$ in 1-day-old mice and stabilizing at $1.29 \pm 0.05$ at 67 days. These data demonstrate statistically significant changes in endbulb complexity with respect to age up to 10 weeks, but no change in endbulbs between the 10-week-old and the 6-7-monthold mice (ANOVA, $p<0.05$ ). As already stated, the fractal index $(1.25 \pm 0.03)$ of endbulbs from $M$ yol $15^{+/ s h 2}$ mice with normal ABR thresholds was not statistically different from those of normal-hearing adult CBA/J mice $(1.29 \pm 0.05)$. The endbulbs of deaf shaker-2 mice were less branched $(1.19 \pm 0.04)$, revealing a twofold reduction in complexity $(p<0.01)$ and implying a structural dependency on hearing.

\section{DISCUSSION}

We have described the age-related development of axosomatic endings that arise from myelinated auditory nerve fibers and terminate in the anterior-most regions of the cochlear nucleus in mice. Although the cochlear nucleus of the newborn mouse is immature and strikingly different in internal appearance from that of adult mice, we nevertheless propose that the small, axosomatic swellings evident just after birth mature into larger club-shaped endings, and finally blossom into an intricate network of branches interconnected by fine filaments known as endbulbs of $\mathrm{H}$ eld. This inferred sequence of development is consistent with earlier findings in the cat (Ryugo and Fekete 1982) but reveals that the mouse auditory system is relatively less mature at birth. 

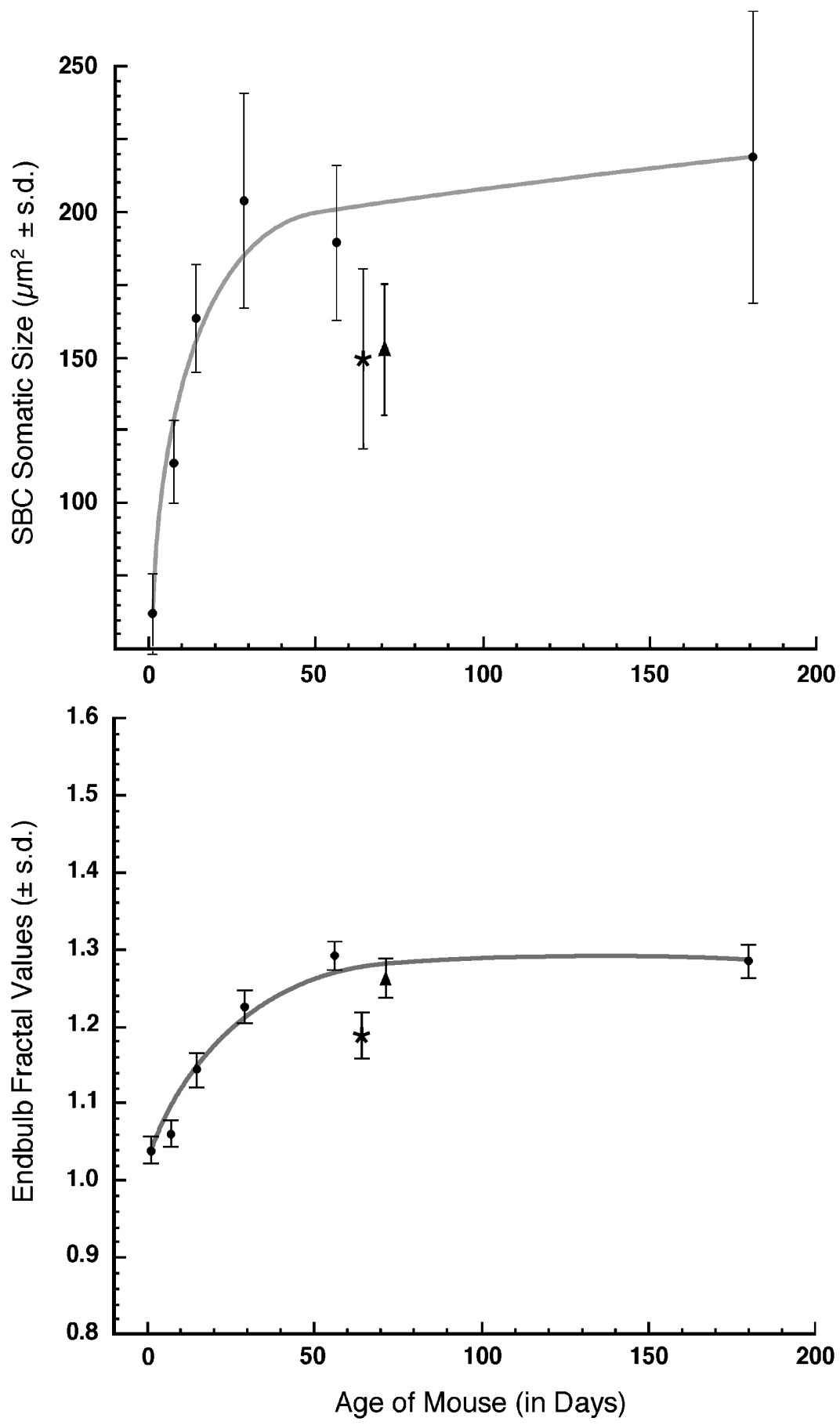

FIG. 10. Graphs presenting quantitative data for $\mathrm{CBA} / \mathrm{J}$ mice (filled circles), deaf adult $M y 015^{\text {sh2/sh2 }}$ mice (asterisks), and hearing adult M yo $15^{+/ s h 2}$ littermates (filled triangles). Top. M ean cross-sectional area ( \pm S.D.) of spherical bushy cells of CBA/J mice as a function of age. Spherical bushy cell size undergoes a rapid, statistically significant age-related increase from $62.9 \pm 14 \mu \mathrm{m}^{2}$ at birth to $204.0 \pm 36.7 \mu \mathrm{m}^{2}$ at 4 weeks of age. After one month, a plateau is reached and cell body size remains stable. There is a significant difference in cell body size between normal-hearing CBA/J mice and deaf shaker-2 mutants and their hearing littermates. There is no difference, however, in somatic size for spherical bushy cells of $\mathrm{M}$ yo $15^{\text {sh2/sh2 }}$ or M yo15 $15^{+/ s h 2}$ mice. Bottom. This graph illustrates the change in fractal index with age in $\mathrm{CBA} / \mathrm{J}$ mice. Fractal values undergo a marked increase during the first 9 weeks of life, at which time the adult endbulb structure is reached and stabilizes. Endbulb complexity is similar for hearing mice but seriously reduced in the deaf Myo15 sh2/sh2 mice. Collectively, these graphs emphasize the idea that the first 2 months of life in the mouse represent a period during which significant growth, change, and structural refinement occur, and where endbulb elaboration is compromised by congenital deafness.
In addition, we examined the structure of endbulbs in adult mutant shaker-2 ( $M$ yol $15^{\text {sh2/ sh2 }}$ ) mice and compared it with that of normal-hearing heterozygous littermates ( $\mathrm{M}$ yol $5^{+/ \text {sh } 2}$ ) and CBA/ J mice. Homozygous mutants $\left(M\right.$ yol $15^{\text {sh2/sh2 }}$ ) and heterozygous littermates ( $\mathrm{M}$ yo15 $5^{+/ \text {sh } 2}$ ) were smaller than CBA/ J mice, as manifested by smaller body weights. These mice also had smaller spherical bushy cells. There was, however, no statistical difference in body weight or spherical bushy cell size between these two groups of littermates. In contrast, there was a significant difference in endbulb morphology between the $M$ yol $15^{\text {sh2/sh2 }}$ and $M$ yol $15^{+/ \text {sh2 }}$ mice. In the deaf $M$ yol $5^{\text {sh } 2 / \text { sh2 }}$ mouse, mature endbulbs exhibit a loss of structural complexity as evidenced by a smaller fractal index. There was no difference in endbulb complexity between $\mathrm{M}$ yo1 $15^{+/ \text {sh } 2}$ and $\mathrm{CBA} / \mathrm{J}$ mice. These findings on endbulbs in the deaf mouse are consistent with observations in the congenitally 


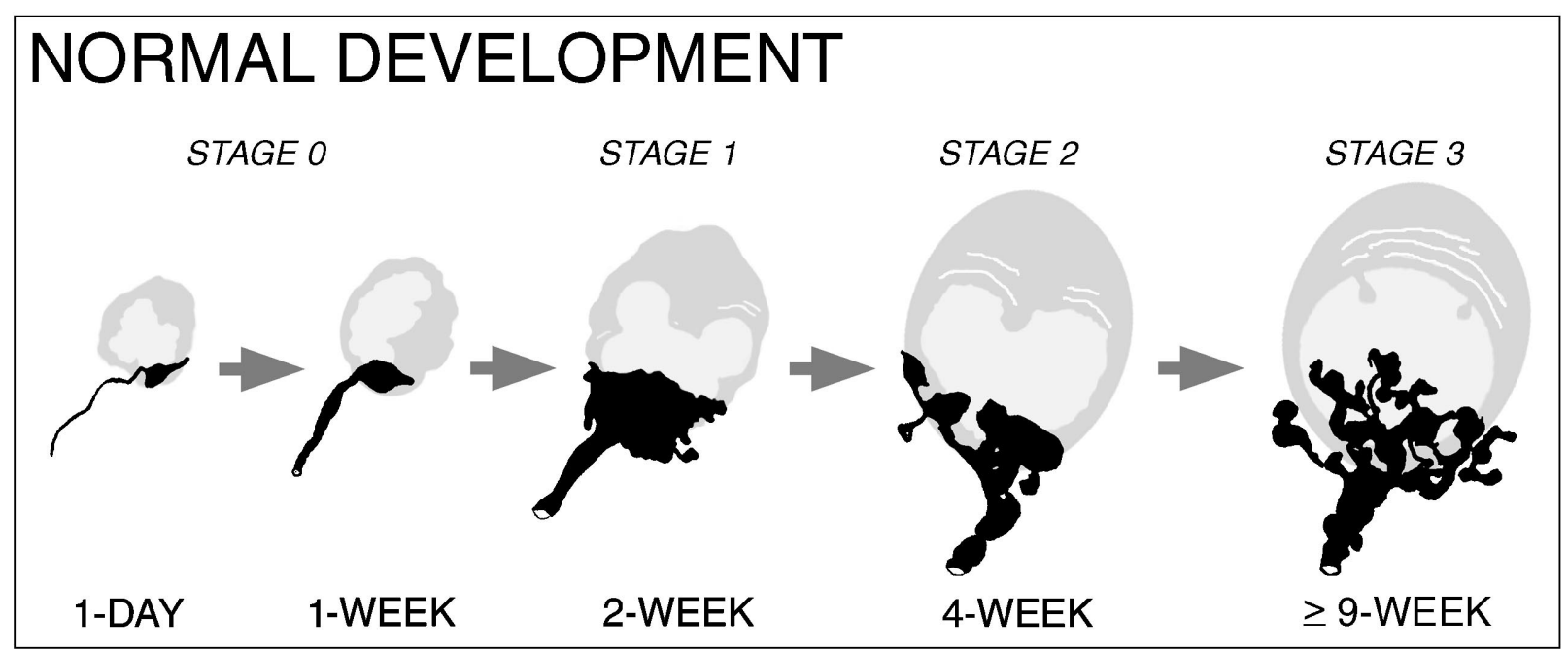

\section{DEVELOPMENT IN DEAFNESS}
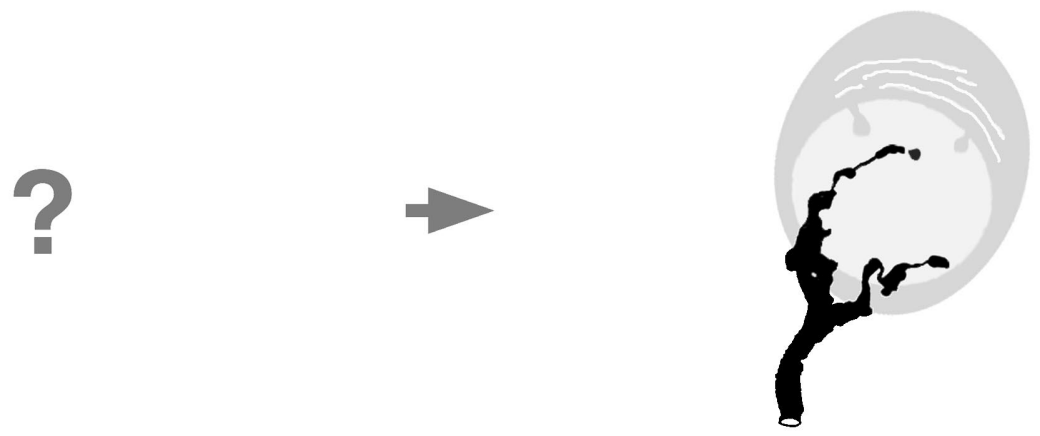

DEAF ADULT

FIG. 11. Top. Schematic diagram showing light microscopic developmental changes in the endbulb of $\mathrm{Held}$ in normal-hearing CBA/J mice. The endbulb begins as a small bouton (Stage 0 ), grows rapidly in size to a large club-shaped ending by two weeks of age (Stage 1), forms definite branches by 4 weeks of age (Stage 2), and reaches its mature shape by 9 weeks of age (Stage 3). After this age, the appearance of the endbulb does not undergo significant change. Bottom. Schematic diagram showing the appearance of the adult endbulb of

deaf white cat (Ryugo et al. 1997, 1998) and implicate a strong influence exerted by auditory deprivation on synaptic structure.

\section{Endbulb staging}

The terminal swellings of auditory nerve fibers in the AVCN exhibit a graded range of appearances, but with a predominant form at each age that we define as a stage (Fig. 11, top panel). Each stage is distinctly more complex than the previous one as determined by fractal analysis. At the earliest ages, the presumptive endbulb appears as a simple, small bouton. During
$\mathrm{Held}$ in the deaf $M$ yo $15^{\text {sh2/sh2 }}$ mice. The endbulb exhibits a reduction in structural complexity and a loss of secondary and tertiary branching. Interconnections between branches are generally absent. Fractal index measurements indicate that the endbulbs of deaf $M$ yo15 $5^{\text {sh2/sh2 }}$ mice are roughly half as complex as that of normalhearing $\mathrm{CBA} / \mathrm{J}$ mice or $\mathrm{MyO} 15^{+/ \mathrm{sh} 2}$ littermates. The question mark indicates the absence of data concerning developmental changes associated with deafness.

the next 2 weeks, this bud continues to enlarge, forming the classic club-shaped 'ending with filopodial extensions (Held 1893; Ramon y Cajal 1909; Lorente de No 1981). This clublike form of the endbulb was previously defined as the Stage 1 endbulb in the newborn cat (Ryugo and Fekete 1982). It appears that endbulbs of newborn mice have not yet reached this first developmental stage, and that cats are probably born after their endbulbs pass through the small bouton stage. For these reasons, we refer to the bouton endings of the immediately postnatal auditory nerve in the mouse as Stage 0 endbulbs. Mice do not exhibit Stage 1 endbulbs until about 2 weeks of age. By the 
4th week, the endbulb has sprouted several branches and has become somewhat irregular in form. This form of the endbulb is equivalent to the Stage 2 endbulb in cats. At 9 weeks postnatal, endbulbs have become more complex in arrangement, with extensive secondary and tertiary branching that covers a large portion of the postsynaptic cell. By this age, the endbulb is considered to be adultlike and is called Stage 3. Beyond this age, endbulbs do not change in branching complexity. Thus, endbulbs of postnatal mice begin at an earlier stage than in cats but pass through the same general stages of development. This morphogenetic sequence of endbulb maturation in mammals is very reminiscent of that in birds (Jhaveri and Morest 1982).

\section{Branching of endbulbs}

In the mature endbulbs of $\mathrm{Held}$, it has been shown that average levels of spike activity influence ending morphology and synaptic structure (Ryugo et al. 1996). High levels of activity are associated with endbulbs having larger but fewer components and containing small release sites. In contrast, low levels of activity are associated with endbulbs having more but smaller components and containing larger release sites. Asour data indicate, congenital deafness isassociated with a lack of presynaptic activity (Ryugo et al. 1998), which is correlated with significant changes in endbulb morphology as reflected by the decrease in branching complexity. It remains to be determined, however, if the morphology of all auditory nerve endings is altered by congenital deafness.

Depolarization or electrical field potentials are known to influence the branching of axonsand formation of lamellipodia in cultured cortical neurons ( Ranmakers et al. 1998; Stewart et al. 1995; Erskine et al. 1995). Although the mechanisms underlying this branching phenomenon remain to be determined, voltage-dependent calcium channels represent one likely source of this activity-dependent growth. Reduction of calcium activity blocks the effect of electrical current on branching (Erskine et al. 1995; Stewart et al. 1995; Graf and Cooke 1994). In the case of endbulbs, normal development with an intact peripheral auditory system might serve to maintain a certain minimum level of electrical activity in auditory nerve fibers, which could in turn trigger voltage-gated calcium channels and promote terminal branching. In the case of deafness, however, the reduction in auditory nerve activity and calcium influx might diminish terminal branching in endbulbs. Although our data do not provide direct evidence to support or refute these ideas, the proposed mechanism is consistent with the observations in endbulb morphology associated with deafness (Fig. 11, bottom panel).
Although it is plausible that alterations in myosin 15 could disrupt the cytoskeleton of the endbulb, such an explanation does not seem likely at this time. Certainly, the mechanisms of a cytoskeletal deficiency producing endbulb deformities would be different from those caused by transduction failure in cochlear hair cell receptors. Myosin 15 is one of a number of subclasses of a large superfamily of actin-dependent molecular motors (Sellers 2000). Conventional myosins form filaments in muscle and nonmuscle cells, but the function of unconventional myosins is little understood. Some of these unconventional myosins are implicated in membrane trafficking, cell movements, and signal transduction (Mermall et al. 1998), whereas others (myosins VI, VIIA, and XV) seem to function in the process of sound transduction (Friedman et al. 1999; Keats and Berlin 1999). Myosin 15 is expressed primarily in the developing cochlear and vestibular sensory epithelia and in the pituitary gland (Liang et al. 1999; Probst et al. 1998). Its apparent absence in the brain stem suggests that it is not a normal component of the endbulb.

\section{Deafness and the development of hearing}

The mouse is a compelling model for study because of its homogenous genetic background, its potential for gene manipulation with transgenic techniques, and its relative immaturity at birth. The auditory system is not completely functional at birth but its proper maturation may be dependent upon the precise timing of acoustic stimulation. The onset of hearing in the mouse occurs around postnatal day 11 but the thresholdsare roughly $70 \mathrm{~dB}$ above those of adults (Mikaelian and Ruben 1965; Ehret 1976). Preyer's reflex, the acoustic startle response, is present by 9 - 14 days of age, around the time that sound-evoked cochlear potentials first appear (Alford and Ruben 1963). The organ of Corti exhibits a nearly mature appearance by the end of the second week but continues to undergo morphologic changes until the end of the second month (Kraus and Aulbach-Kraus 1981). Mesenchyme clears from the middle ear space by postnatal days 14-16 (Mikaelian and Ruben 1965), but the ear canal itself is not always patent along its entire length until the end of the third week (unpublished observations). Clearly, there is anorchestrated pattern of development where structure and function interact.

There is an important distinction to be made between onset of hearing and functional hearing. By the time that the external ear canal became patent ( after postnatal week 3 ), the mice exhibited stable ABR thresholds and waveforms, in spite of the continued structural maturation of the endbulbs of $\mathrm{H} \mathrm{eld}$. It is the period between hearing readiness (around postnatal week 2) and cochlear (Kraus and Aulbach-Kraus 1981) 
and auditory nerve maturation (around postnatal week 8) in which crucial interplay between sensory in put and proper development occurs. Environmental sounds presumably ser ve to "validate" the genetic program once the animal begins to hear. Given that normal mice have very high auditory thresholds until the second postnatal week, the ability to hear apparently does not influence early brain development. O ur demonstration that deafness produces highly abnormal endbulbs of $\mathrm{H}$ eld by postnatal week 8 emphasizes the role of sound on development. What is not known is the level of spike activity in auditory nerve fibers of the developing mouse and when such activity becomes important.

It is striking that endbulbs of deaf $M$ yol $15^{\text {sh2/sh2 }}$ mice have a similar appearance to those of congenitally deaf white cats (Ryugo et al. 1997, 1998). In deaf white cats, there is a marked reduction of endbulb arborization complexity and an associated hypertrophy of postsynaptic densities (Ryugo et al. 1997). Because of the unknown genetic background of the deaf white cat, it is not known definitively whether endbulb and synaptic changes are the consequences of deafness or result from the constellation of pathologies associated with the genetic syndrome. Cochleosaccular degeneration seen in the deaf white cat raised the question of secondary changes in the cochlear nucleus in response to organ of Corti deterioration. The genetic differences between deaf white cats and $M$ yol $15^{\text {sh2/ sh2 }}$ mice, however, imply that the manifestations in endbulb abnormalities are attributable to deafness, the main common variable. The most parsimonious interpretation for the collective data is that the endbulb synapse is responsive not only to normal variations in activity (Ryugo et al. 1996) but also to the pathologic absence of sound (Ryugo et al. 1997, 1998). Interestingly, the structure of these abnormal endbulbs does not resemble a state of arrested development because endbulbs of normalhearing mice and cats do not pass through as tage where they resemble those of congenitally deaf animals.

$\mathrm{H}$ air cell loss within the cochlea is the most common cause of sensorineural hearing loss (Kveton and Pensak 1995). However, outcomes achieved in the treatment of hearing disorders suggest that providing acoustic information to the brain via cochlear implantation is not by itself always sufficient to restore functionally useful hearing. Postlingually deaf patients appear to benefit more from cochlear implants than prelingually deaf patients, and younger children benefit more than older children (Nikolopoulos et al. 1999; Waltzman et al. 1994; Gantz et al. 1994). The endbulbs of $\mathrm{Held}$, thought to be indispensable for the temporal processing of sound, may be especially relevant to the acquisition of language because speech comprehension relies upon accurate temporal coding of acoustic input. Our data reveal that maturation of the endbulb and spherical bushycell in the mouse proceeds rapidly during the first month of life and continues steadily through the second. It is plausible, then, that deafness disrupts early developmental events during this period, these in turn are responsible for the differential effects of hearing loss on young versus old populations. The efficacy of treatments for deafness might be improved with a better understanding of the exact nature of the changes that occur at the earliest periods of auditory development. By comparing the changes seen in deafness with those seen in normal cases, we may also derive insight into the significance of specific time periods for proper development and the role of activity in synaptogenesis.

\section{ACKN O W LED G MENTS}

The authors wish to thank M. Christian Brown for his assistance with cochlear surger $\mathrm{y}, \mathrm{H}$ ugh Cahill and Melissa Gorelikow for technical assistance, Frank J. Probst for advice on shaker-2 mice, and John R. Doucet for valuable discussions of the data. Parts of these data were presented in preliminary form at the 22nd M idwinter Research M eeting of the Association for Research in Otolaryngology, St. Petersburg Beach, FL, Feb. 13-18, 1999. This work was supported by NIH/ NIDCD research grant DC00232, NIH/ NIDCD training grant DC00027, and a resident research grant from the American Academy of Otolaryngology-Head and Neck Surgery Foundation.

\section{REFEREN CES}

Alford BR, Ruben RJ. Physiological, behavioral and anatomical correlates of the development of hearing in the mouse. Ann. Otol. 72:237-247, 1963.

BLACKBURN CC, SACHS MB. The representations of the steady-state vowel $/ \varepsilon /$ in the discharge patterns of cat anteroventral cochlear nucleus neurons. J. Neurophysiol. 63:1191-1212, 1990.

BRAWER JR, M OREST DK. Relations between auditory nerve endings and cell types in the cat's anteroventral cochlear nucleus seen with the Golgi method and Nomarski optics. J. Comp. Neurol. 160:491-506, 1975.

BURKARD R. Sound pressure level measurement and spectral analysis of brief acoustic transients. Electroenceph. clin. Neurophysiol. 57:83-91, 1984.

CANT NB, CASSEDAY JH. Projections from the anteroventral cochlear nucleus to the lateral and medial superior olivary nuclei. J. Comp. Neurol. 247:457-476, 1986.

CANT NB, MOREST DK. The bushy cells in the anteroventral cochlear nucleus of the cat. A study with the electron microscope. N euroscience. 4:1925-1945, 1979

CRISPENS CG JR. Handbook on the Laboratory Mouse Charles C Thomas Springfield, IL, 1975. 
DEOL MS. The anomalies of the labyrinth of the mutants varitintwaddler, shaker-2 and jerker in the mouse. J. Genet. 52:562-588, 1954.

EHRET G. Development of absolute auditory thresholds in the house mouse (M us musculus). J. Am. Audiol. Soc. 1:179-184, 1976.

ERSKInE L, SteWART R, McCaIg CD. Electric field-directed growth and branching of cultured frog nerves: Effects of aminoglycosides and polycations. J. Neurobiol. 26:523-536, 1995.

FitzPatrick DC, Batra R, Stanford TR, Kuwada S. A neuronal population code for sound localization. Nature. 388:871-874, 1997.

Friedman TB, Sellers JR, Avraham KB. Unconventional myosins and the genetics of hearing loss. Am. J. Med. Genet. 89:147-157, 1999. DOI:10.1002/ (SICI) 1096-8628 19990924 89:3 < 147::AID AJMG5 > 3.0.CO;2-6.

Gantz B, Tyler R, Woodworth G, Tye-Murray N, FryaufBERTSCHYH. Results of multichannel cochlear implantsin congenital and acquired prelingual deafness in children: Five year follow up. Am. J. Otol. 15:1-8, 1994

Graf RA, COOKE IM. Outgrowth morphology and intracellular calcium of crustacean neurons displaying distinct morphologies in primary culture. J. Neurobiol. 25:1558-1569, 1994.

HeLd H. Die centrale Gehorleitung. Arch. Anat. Physiol. Anat. Abt. 201-248, 1893.

HENRY KR. Ageing and audition. WILLOTT JF, The Auditory Psychobiology of the M ouse CharlesC. Thomas Springfield 1983, 470-493.

HUNTER KP, WILLOTT JF. Aging and the auditory brainstem response in mice with severe or minimal presbycusis. Hear. Res. 30:207218, 1987.

JHAVERI S, MoREST DK. Sequential alterations of neuronal architecture in nucleus magnocellularis of the developing chicken: a Golgi study. Neuroscience. 7:837-853, 1982.

KeATS BJB, BerLIN Cl. Genomics and hearing impairment. Genome Res. 9:7-16, 1999

Kraus HJ, Aulbach-Kraus K. Morphological changes in the cochlea of the mouse after the onset of hearing. Hear. Res. 4:89$102,1981$.

Kveton JF, Pensak ML. Cochlear implantation.

LEE JK. Essential O tolaryngology Appleton and Lange, $\mathrm{New} \mathrm{H}$ aven, CT 1995, 161-172.

LENN NJ, REESE TS. The fine structure of nerve endings in the nucleus of the trapezoid body and the ventral cochlear nucleus Am. J. Anat. 118:375-390, 1966.

Liang Y, Wang A, Belyantseva IA, Anderson DW, Probst FJ, Barber TD, Miller W, Touchman JW, Jin L, Sullivan SL, Sellers JR, Camper SA, Kachar B, Friedman TB, Fridell RA. Characterization of the human and mouse unconventional myosin $X V$ genes responsible for hereditary deafness DFNB3 and shaker 2. Genomics. 61:243-258, 1999. 10.1006/ geno.1999.5976.

Lorente DE No R. The Primary Acoustic Nuclei Raven Press New York 1981.

MANDELBROT BB. The Fractal Geometry of Nature Freeman New York 1982

MANIS PB, MARX SO. O utward currents in isolated ventral cochlear nucleus neurons. J. Neurosci. 11:2865-2880, 1991.

Mermall V, Post PL, Mooseker MS. Unconventional myosins in cell movement, membrane traffic, and signal transduction. Science. 279:527-533, 1998.

MiKAELIAN D, Ruben RJ. Development of hearing in the normal CBA-J mouse. Acta Otolaryngol. 59:451-461, 1965.

MoISEFF A, KONISHI M. Neuronal and behavioral sensitivity to binaural time differences in the owl. J. Neurosci. 1:2553-2562, 1981.

Nikolopoulos TP, O'Donoghue GM, ARCHBold S. Age at implantation: Its importance in pediatric cochlear implentation. Laryngoscope. 109:595-599, 1999.
OERTEL D. Synaptic responses and electrical properties of cells in brain slices of the mouse anteroventral cochlear nucleus. J. Neurosci. 3:2043-2053, 1983.

O SEN KK. Cytoarchitecture of the cochlear nuclei in the cat. J. Comp. Neurol. 136:453-482, 1969.

Pfeiffer RR. Anteroventral cochlear nucleus: Wave forms of extracellularly recorded spike potentials. Science. 154:667-668, 1966.

Porter R, Ghosh S, LANGE GD, SMIth JR TG. A fractal analysis of pyramidal neurons in mammalian motor cortex. Neurosci. Lett. 130:112-116, 1991.

Probst FJ, Fridell RA, Raphael Y, Saunders TL, Wang A, Liang Y, Morell RJ, Touchman JW, Lyons RH, Noben-Trauth K, Friedman TB, Cam Per SA. Correction of deafness in shaker-2 mice by an unconventional myosin in a BAC transgene. Science. 280:1444-1447, 1998

Ramon y C'AJAL R. Histologie du Systeme Nerveux de I'Homme et des Vertebres Instituto Ramon y Cajal Madrid 1909.

Ranmakers GJ, Winter J, Hoogland TM, Lequin MB, VAN HuLten P, VAN PELT J, POOL CW. Depolarization stimulates lamellipodia formation and axonal but not dendritic branching in cultured rat cerebral cortex neurons. Dev. Brain Res. 108:205-216, 1998 DOI:10.1016/ S0165-3806 98 00050-9.

ROMAND R. Survey of intracellular recording in the cochlear nucleus of the cat. Brain Res. 148:43-65, 1978.

RYUGO DK, FEKETE DM. Morphology of primary axosomatic endings in the anteroventral cochlear nucleus of the cat: A study of the endbulbs of Held J. Com. Neurol. 210:239-257, 1982.

Ryugo DK, Pongstaporn T, Huchton DM, Niparko JK. U Itrastructural analysis of primary endings in deaf white cats: Morphologic alterations in endbulbs of Held. J. Comp. Neurol. 385:230-244, 1997. DOI:10.1002/ (SICI) 1096-9861 19970825 385:2 < 230::AID CNE4 > 3.0.CO;2-2.

Ryugo DK, Rosenbaum BT, Kim PJ, Niparko JK, Saada AA. Single unit recordings in the auditory nerve of congenitally deaf white cats: morphological correlates in the cochlea and cochlear nucleus. J. Comp. Neurol. 397:532-548, 1998. DOI:10.1002/ ( $\mathrm{SICl}$ ) 1096-9861 19980810 397:4 < 532::AID-CNE6 > 3.0.CO ;2-2.

RYugo DK, Wu MM, PONGSTAPORN T. Activity-related features of synapse morphology: A study of endbulbs of $\mathrm{H}$ eld. J. Comp. Neurol. 365:141-158, 1996. DOI:10.1002/ (SICI) 1096-9861 19960129 365:1 < 141::AID-CNE11 > 3.0.CO;2-T.

SeLLERS JR. M yosins: a diverse superfamily. Biochim. Biophys. Acta. 1496:3-22, 2000.

Shnerson A, Pujol R. Development: Anatomy, electrophysiology and behavior. WILLOTT JF, The Auditory Psychobiology of the Mouse. Charles C Thomas, Springfield, IL, 1983, 395-425.

So KOLICH WG. Improved acoustic system for auditory research. J. Acoust. Soc. Am. Suppl. 62:S12, 1977.

Stewart R, ERskine L, MCCAig CD. Calcium channel subtypes and intracellular calcium storesmodulate electric field-stimulated andoriented nerve growth. Dev. Biol. 171:340-351, 1995. DOI: 10.1006/ dbio.1995.1286.

TAKAHASH T, MoISEFF A, KonISHI M. Time and intensity cues are processed independently in the auditory system of the owl. J. Neurosci. 4:1781-1786, 1984.

WALTZMAN SB, COHEN NL, SHAPIRO WH. Long term results of earlycochlear implantation in congenitally and prelingually deafened children. Am. J. Otol. 15:9-31, 1994.

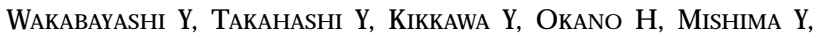
USHIKI T, YONeKaWA H, KominamI R. A novel type of myosin encoded by the mouse deafness gene shaker-2. Biochem. Biophys. Res. Commun. 248:655-659, 1998. DOI:10.1006/ bbrc.1998.8976.

Wang A, LiAng Y, Fridell RA, Probst FJ, Wilcox ER, Touchman JW, Morton CC, Morell RJ, Noben-Tauth K, Camper SA, Fried- 
MAN TB. Association of unconventional myosin MYO 15 mutations with human nonsyndromic deafness DFNB3. Science 280:14471451, 1998.

Webster DB, Trune DR. Cochlear nuclear complex of mice. Am. J. Anat. 163:103-130, 1982.

WENNGREN B, ANNIKo M. A frequency-specific auditory brainstem response technique exemplified in the determination of age- related auditory thresholds. Acta O tolaryngol. (Stockh.) 106:238243, 1988.

YIN TCT, CHAN JCK. Interaural time sensitivity in medial superior olive of cat. J. Neurophysiol. 64:465-488, 1990.

ZHENG QY, JOHNSON KR, ERWAY LC. Assessment of hearing in 80 inbred strains of mice by $A B R$ threshold analyses. Hear. Res. 130:94-107, 1999. DOI:10.1016/ S0378-5955 (99) 00003-9. 